\title{
PEMBUATAN BAKSO HERBAL DARI JAMUR TIRAM PUTIH (Pleurotus ostreatus) DAN KAYU MANIS (Cinnamomum burmannii) UNTUK MENURUNKAN KADAR KOLESTEROL
}

\author{
Daffa Farhan Alfarros ${ }^{1 *}$, Dewi Ratnasari², Agus Djamaludin ${ }^{3}$
}

1,2,3Sekolah Kesehatan Holistik Purwakarta

*Korespondensi: Jl. Veteran No. 272 Ciseureuh Purwakarta, Email: daffafarhanalfarros@gmail.com

\begin{abstract}
ABSTRAK
Latar Belakang: Kolesterol adalah lemak yang terdapat di dalam aliran darah atau sel tubuh yang dibutuhkan untuk pembentukan dinding sel dan sebagai bahan baku beberapa hormon. Apabila kolesterol di atas $240 \mathrm{mg} / \mathrm{dl}$, maka berisiko tinggi terkena penyakit seperti serangan jantung atau stroke. Pencegahan terbaik untuk menurunkan kolesterol yaitu menjaga pola makan dengan baik.

Tujuan Penelitian: Penelitian ini bertujuan membuat bakso herbal dari jamur tiram putih (Pleurotus ostreatus) dan kayu manis (Cinnamomum burmannii) yang secara empiris bermanfaat untuk menurunkan kadar kolesterol.

Metode: Metode penelitian yang digunakan yaitu penelitian tindakan (action research) menggunakan instrumen penelitian berupa lembar observasi dan angket. Sediaan bakso herbal dibuat dengan bahan utama jamur tiram putih (Pleurotus ostreatus) dan kayu manis (Cinnamomum burmannii) dengan komposisi F1 (200 gram ; 0 gram), F2 (200 gram ; 2,5 gram) dan F2 (200 gram ; 5 gram).

Hasil: Hasil penelitian uji organoleptik selama tiga minggu sediaan bakso dengan penyimpanan suhu dingin tidak timbul perubahan dalam hal warna, aroma, tekstur, rasa dan tidak menimbulkan tanda-tanda tumbuhnya jamur. Sementara pada penyimpanan suhu ruang hanya bertahan selama 2 hari saja.

Simpulan: Simpulan dari penelitian ini adalah sediaan bakso herbal yang disukai yaitu formula kesatu dan sediaan stabil dalam penyimpanan selama 3 minggu pada suhu dingin.
\end{abstract}

Kata kunci: Jamur tiram putih (Pleurotus ostreatus), Kayu manis (Cinnamomum burmannii), Bakso herbal, Kolesterol

\footnotetext{
ABSTRACT

Background: Cholesterol is fat contained in the bloodstream or body cells needed for the formation of cell walls and as a raw material for several hormones. If your cholesterol is above $240 \mathrm{mg} / \mathrm{dl}$, you have a high risk of developing diseases such as heart attack or stroke. The best prevention for lowering cholesterol is to maintain a good diet.

objective: This study aims to make stable herbal meatballs from white oyster mushroom (Pleurotus ostreatus) and cinnamon (Cinnamomum burmannii) which is empirically useful for lowering cholesterol levels.

Method: The research method used is action research using research instruments in the form of observation sheets and questionnaires. Herbal meatball preparations are made with the main ingredients of white oyster mushroom (Pleurotus ostreatus) and cinnamon (Cinnamomum burmannii) with the composition of F1 (200 grams; 0 grams), F2 (200 grams; 2.5 grams) and F2 (200 grams; 5 grams).

Results: The results of the three-week organoleptic test of meatball preparations with cold storage did not show any changes in color, aroma, texture, taste and did not cause any signs of mold growth. Meanwhile, the room temperature storage only lasts for 2 days.
} 
Conclusion: The conclusion from this research is that the preferred herbal meatball preparation is the first formula and the preparation is stable in storage for 3 weeks at cold temperatures.

Keywords: White oyster mushroom (Pleurotus ostreatus), Cinnamon (Cinnamomum burmannii), herbal meatballs, cholesterol

\section{PENDAHULUAN}

Kolesterol adalah lemak yang terdapat di dalam aliran darah atau sel tubuh yang sebenarnya dibutuhkan untuk pembentukan dinding sel dan sebagai bahan baku beberapa hormon. Kolesterol yang normal harus di bawah $200 \mathrm{mg} / \mathrm{dl}$. Apabila di atas $240 \mathrm{mg} / \mathrm{dl}$, maka berisiko tinggi terkena penyakit seperti serangan jantung atau stroke[1].

Pemberian obat golongan statin banyak digunakan oleh tenaga kesehatan sebagai obat yang berfungsi menurunkan kadar kolesterol, namun penggunaan obat sintetis tentunya memiliki efek samping terhadap tubuh[2]. Pencegahan terbaik untuk menurunkan kolesterol yaitu menjaga pola makan dengan baik. Pola makan merupakan suatu hal yang menjadikan kebiasaan seseorang dengan gaya hidup pada era sekarang yang condong kepada hal-hal yang bersifat praktis[3]. Hal ini produsen pangan terus berinovasi mengeluarkan produk pangan yang bersifat praktis namun bergizi misalnya bakso.

Bakso adalah produk pangan olahan daging yang dihaluskan lalu dicampur dengan tepung dan bumbu-bumbu, selanjutnya dibentuk seperti bola-bola kecil dan direbus hingga matang dengan air panas[4]. Pada umumnya bakso dibuat dari olahan daging, namun bakso berbahan baku daging tidak dapat dikonsumsi oleh vegetarian dan umumnya karena berasal dari hewan sehingga mengandung kolesterol.

Masa simpan bakso dalam kondisi normal penyimpanan hanya bisa bertahan 2 hari[5]. Beberapa alternatif untuk mempertahankan daya simpan bakso adalah mengolahnya menjadi bakso beku, namun proses pembekuan memerlukan biaya yang mahal sehingga hanya dilakukan oleh industri besar dengan jangkauan pemasaran yang luas. Alternatif lain adalah dengan metode pengawetan menggunakan zat kimia dan pengawetan alami. Pengawet kimia yang banyak digunakan saat ini adalah formalin tetapi berbahaya untuk kesehatan manusia[6]. Salah satu pengawet alami yang dapat digunakan untuk mengawetkan bakso adalah kayu manis. Kayu manis selama ini berpotensi sebagai antimikroba yang dapat dimanfaatkan sebagai bahan pengawet pada produk makanan. Bubuk kayu manis dapat mengawetkan roti manis selama 7 hari[7], ekstrak kayu manis dapat mengawetkan dodol rumput laut selama 20 hari[8]. Penambahan ekstrak kulit kayu manis 25\% dan lama perendaman 60 menit dapat memperpanjang umur simpan bakso ikan patin selama 60 jam (2,5 hari)[9].

Jamur tiram putih sangat disukai oleh masyarakat karena berkhasiat membantu mengurangi kadar lemak dalam darah, sehingga mampu mencegah penyakit jantung koroner dan gula dalam darah, sehingga jamur tiram putih cocok bagi seseorang yang menjalankan diet, penyakit kolesterol, dan darah tinggi[10]. Jamur tiram putih yang mengandung statin yang dapat menghambat pembentukan kolesterol melalui penghambatan pembentukan HMG-CoA menjadi asam mevalonat[11]. Berdasarkan penelitian oleh mahasiswa Sekolah Ilmu dan Teknologi Hayati (SITH) ITB kelompok ilmuwan Mikrobiologi, Genetika, dan Biologi Molekuler membuktikan bahwa jamur tiram putih (Pleurotus ostreatus) mengandung lovastatin (golongan statin) sebagai penurun kolesterol[12]. Studi lain dari Chilean mushroom menemukan bahwa pada Pleurotus ostreatus terdapat molekul penurun kolesterol. Pleurotus ostreatus mengandung 0,40- 2,07\% lovastatin yang dikultur pada media wheat straw dan $0,7-$ 
$2,8 \%$ lovastatin pada media cair yang diukur pada berat kering[11].

Berdasarkan penelitian oleh mahasiswa Sekolah Ilmu dan Teknologi Hayati (SITH) ITB kelompok ilmuwan Mikrobiologi, Genetika, dan Biologi Molekuler membuktikan bahwa jamur tiram putih (Pleurotus ostreatus) mengandung lovastatin (golongan statin) sebagai penurun kolesterol[12]. Studi lain dari Chilean mushroom menemukan bahwa pada Pleurotus ostreatus terdapat molekul penurun kolesterol. Pleurotus ostreatus mengandung 0,40-2,07\% lovastatin yang

\section{METODE PENELITIAN}

Metode penelitian yang digunakan yaitu penelitian tindakan (action research) menggunakan instrumen penelitian berupa lembar uji organoleptik dan uji kesukaan dengan jumlah responden sejumlah 20 orang dengan semua rentang usia. Pertanyaan kuesioner penelitian uji kesukaan yang dipilih responden yang mewakili persepsi responden mencakup sangat tidak suka, tidak ssuka, netral, suka dan sangat suka sebagai varibel tidak tetap dan penilaian warna, aroma, rasa sebagai variabel tetap. Jumlah atau persentase persepsi responden kemudian diukur menggunakan skala[13].

Alat yang digunakan pada penelitian ini yaitu pisau, talenan, timbangan analitik, sendok, panci, kompor, oven, ayakan 80 mesh, blender dan baskom.

Bahan yang digunakan pada penelitian ini yaitu jamur tiram putih, kayu manis, tepung terigu, tepung tapioka dan bumbu-bumbu (bawang putih, merica, garam dan putih telur).

Pembuatan bakso herbal ini melewati beberapa tahapan, yaitu sebagai berikut:

1. Jamur tiram putih disortir dagingnya saja tanpa tangkai

2. Cuci bersih menggunakan air mengalir

3. Kukus jamur tiram putih selama 15 menit

4. Haluskan jamur tiram putih menggunakan blender, pindahkan ke dalam wadah dikultur pada media wheat straw dan 0,7$2,8 \%$ lovastatin pada media cair yang diukur pada berat kering[11].

Bertolak dari latar belakang inilah peneliti ingin membuat sediaan bakso yang herbal dipilih karena hampir semua kalangan menyukai bakso, mengandung nilai gizi tinggi dan berkhasiat sebagai obat antikolesterol, tidak menggunakan bahanbahan kimia yang berpotensi berbahaya bagi tubuh dan menciptakan suatu produk pangan olahan bakso yang aman dikonsumsi oleh segala kalangan masyarakat dan bermanfaat bagi kesehatan.

5. Tambahkan bumbu-bumbu (bawang putih yang sudah dihaluskan, garam, merica dan putih telur) dan aduk rata

6. Campurkan bubuk kayu manis (sesuai perlakuan)

7. Kemudian campurkan dengan tepung terigu

8. Lalu campurkan tepung tapioka

9. Aduk hingga adonan bakso merata

10. Genggam adonan bakso lalu ditekan supaya adonan bisa keluar dari ibu jari dan telunjuk, lalu diambil dengan sendok

11. Direbus dengan air yang sudah mendidih

12. Rebus hingga bakso mengapung, lalu ditiriskan dan kemas

\section{Perlakuan Penelitian}

$\mathrm{F} 1$ = Bakso jamur tiram putih tanpa kayu manis

$\mathrm{F} 2=$ Bakso jamur tiram putih dengan 2,5 gram bubuk kayu manis

F3 = Bakso jamur tiram putih dengan 5 gram bubuk kayu manis

\section{Parameter Pengamatan Uji Organoleptik}

Uji organoleptik atau uji indera merupakan cara pengujian dengan menggunakan indera manusia sebagai alat utama untuk pengukuran daya penerimaan terhadap produk. Indra yang digunakan dalam menilai sifat indrawi adalah indera penglihatan, peraba, pembau dan pengecap. Pengamatan organoleptik pada sediaan 
bakso herbal yang akan dilakukan yaitu untuk mengetahui ada tidaknya perubahan warna, aroma, tekstur, rasa dan ada tidaknya pertumbuhan jamur. Pengamatan organoleptik ini dilakukan selama 3 minggu dengan perbandingan suhu ruang dan suhu dingin pada suatu bakso herbal.

\section{Uji Kesukaan}

Uji kesukaan (Hedonik) merupakan pengujian yang paling banyak digunakan untuk mengukur tingkat kesukaan terhadap produksi. Tingkat kesukaan ini disebut skala hedonik, misalnya sangat suka, suka,

\section{HASIL PENELITIAN}

\section{Uji Organoleptik}

agak suka, agak tidak suka, tidak suka, sangat tidak suka dan lain-lain[14].

Uji kesukaan adalah berupa kesan atau komentar yang diberikan oleh panelis tentang baik dan buruknya suatu produk dengan parameter yang diuji yaitu aroma, rasa dan warna[15].

\section{Analisis Data}

Analisis data yang digunakan penulis adalah naratif dan interpretatif. Analisis ini dipilih karena penulis mendeskripsikan hasil pengamatan penelitian dalam bentuk narasi dan melakukan pengkajian hasil penelitian terhadap kajian pustaka yang dilakukan sebelumnya.

Tabel 1.1 Hasil Uji Organoleptik

\begin{tabular}{|c|c|c|c|c|c|c|c|}
\hline Penyimpanan & Waktu & Sampel & Warna & Aroma & Tekstur & Rasa & $\begin{array}{c}\text { Ada Tidaknya } \\
\text { Pertumbuhan Jamur }\end{array}$ \\
\hline \multirow{3}{*}{ Suhu Dingin } & \multirow{3}{*}{21 hari } & $\mathrm{F} 1$ & $\begin{array}{c}\text { Putih } \\
\text { kecoklatan }\end{array}$ & $\begin{array}{l}\text { Khas jamur tiram } \\
\text { putih }\end{array}$ & $\begin{array}{l}\text { Sedikit } \\
\text { kenyal }\end{array}$ & $\begin{array}{l}\text { Sedikit } \\
\text { gurih }\end{array}$ & Tidak tumbuh jamur \\
\hline & & $\mathrm{F} 2$ & $\begin{array}{l}\text { Coklat } \\
\text { pucat }\end{array}$ & $\begin{array}{c}\text { Khas jamur tiram } \\
\text { putih dan kayu } \\
\text { manis }\end{array}$ & $\begin{array}{l}\text { Sedikit } \\
\text { kenyal }\end{array}$ & $\begin{array}{l}\text { Gurih } \\
\text { agak } \\
\text { pahit }\end{array}$ & Tidak tumbuh jamur \\
\hline & & F3 & $\begin{array}{l}\text { Coklat } \\
\text { gelap }\end{array}$ & Khas kayu manis & $\begin{array}{l}\text { Sedikit } \\
\text { kenyal }\end{array}$ & Pahit & Tidak tumbuh jamur \\
\hline \multirow{6}{*}{ Suhu Ruang } & \multirow{3}{*}{1 hari } & $\mathrm{F} 1$ & $\begin{array}{c}\text { Putih } \\
\text { kecoklatan }\end{array}$ & $\begin{array}{c}\text { Khas jamur tiram } \\
\text { putih }\end{array}$ & $\begin{array}{l}\text { Sedikit } \\
\text { kenyal }\end{array}$ & $\begin{array}{l}\text { Sedikit } \\
\text { gurih }\end{array}$ & Tidak tumbuh jamur \\
\hline & & $\mathrm{F} 2$ & $\begin{array}{l}\text { Coklat } \\
\text { pucat }\end{array}$ & $\begin{array}{c}\text { Khas jamur tiram } \\
\text { putih dan kayu } \\
\text { manis }\end{array}$ & $\begin{array}{l}\text { Sedikit } \\
\text { kenyal }\end{array}$ & $\begin{array}{l}\text { Gurih } \\
\text { agak } \\
\text { pahit }\end{array}$ & Tidak tumbuh jamur \\
\hline & & F3 & $\begin{array}{l}\text { Coklat } \\
\text { gelap }\end{array}$ & Khas kayu manis & $\begin{array}{l}\text { Sedikit } \\
\text { kenyal }\end{array}$ & Pahit & Tidak tumbuh jamur \\
\hline & \multirow{3}{*}{2 hari } & $\mathrm{F} 1$ & Putih & Berbau & $\begin{array}{l}\text { Sedikit } \\
\text { kenyal }\end{array}$ & - & Tumbuh jamur \\
\hline & & $\mathrm{F} 2$ & Putih & Berbau & $\begin{array}{l}\text { Sedikit } \\
\text { kenyal }\end{array}$ & - & Tumbuh jamur \\
\hline & & F3 & Putih & Berbau & $\begin{array}{l}\text { Sedikit } \\
\text { kenyal }\end{array}$ & - & Tumbuh jamur \\
\hline
\end{tabular}

* Sampel : F1 (Formulasi satu), F2 (Formulasi dua), F3 (Formulasi tiga

Pada penyimpanan disuhu dingin dengan pengujian organoleptik selama 3 minggu didapatkan hasil yakni tidak timbul perubahan dalam hal warna, aroma, tekstur, rasa dan pertumbuhan jamur.

Pada sampel F1 warna yang timbul yakni putih kecoklatan, aroma dan rasa jamur putih yang khas serta tekstur yang sedikit kenyal.

Pada sampel F2 warna yang timbul yakni coklat pucat, aroma dan rasa yang khas jamur tiram putih serta kayu manis, ini sebabkan karena penambahan sedikit bubuk kayu manis 2,5 gram pada sediaan tersebut serta tekstur yang sedikit kenyal.

Pada sampel F3 warna yang timbul yakni coklat gelap, aroma dan rasa yang khas kayu manis, ini sebabkan karena penambahan bubuk kayu manis 5 gram pada sediaan tersebut serta tekstur yang sedikit kenyal. 
Sedangkan pada penyimpanan di suhu ruang didapatkan hasil pada hari kedua ketiga sampel formula sediaan bakso Uji Kesukaan herbal sudah mengalami perubahan warna, aroma, tekstur, rasa dan tumbuhnya jamur.

Tabel 1.2 Hasil Uji Kesukaan Responden

\begin{tabular}{|c|c|c|c|c|c|c|c|}
\hline \multirow{2}{*}{$\begin{array}{c}\text { Jumlah } \\
\text { Responden }\end{array}$} & \multirow{2}{*}{ Kriteria Uji Kesukaan } & \multirow{2}{*}{ Sampel } & \multicolumn{5}{|c|}{ Hasil Uji Kesukaan Responden } \\
\hline & & & Sangat Suka & Suka & Netral & Tidak Suka & Sangat Tidak Suka \\
\hline \multirow{9}{*}{20} & \multirow{3}{*}{ Warna } & $\mathrm{F} 1$ & 0 & 10 & 7 & 3 & 0 \\
\hline & & $\mathrm{F} 2$ & 0 & 13 & 5 & 2 & 0 \\
\hline & & F3 & 0 & 1 & 7 & 12 & 0 \\
\hline & \multirow{3}{*}{ Aroma } & F1 & 0 & 6 & 14 & 0 & 0 \\
\hline & & $\mathrm{F} 2$ & 0 & 4 & 14 & 2 & 0 \\
\hline & & F3 & 0 & 0 & 9 & 11 & 0 \\
\hline & \multirow{3}{*}{ Rasa } & $\mathrm{F} 1$ & 0 & 12 & 7 & 1 & 0 \\
\hline & & $\mathrm{F} 2$ & 0 & 11 & 6 & 3 & 0 \\
\hline & & F3 & 0 & 1 & 2 & 17 & 0 \\
\hline
\end{tabular}

*Sampel : F1 (Formulasi satu), F2 (Formulasi dua), F3 (Formulasi tiga)

Tabel 1.2 menunjukan hasil uji kesukaan dari 20 responden. Hasil uji diubah kedalam hitungan presentase yang kesukaan responden tersebut kemudian dapat dilihat pada Tabel 1.3.

Tabel 1.3 Hasil Persentase Uji Kesukaan

\begin{tabular}{|c|c|c|c|c|c|c|c|c|c|c|c|}
\hline \multirow{2}{*}{$\begin{array}{c}\text { Uji } \\
\text { Kesukaan }\end{array}$} & \multirow{2}{*}{ Sampel } & \multicolumn{10}{|c|}{ Skor Persentase Penilaian Uji Kesukaan (\%) } \\
\hline & & \multicolumn{2}{|c|}{ SS } & \multicolumn{2}{|c|}{$\mathrm{S}$} & \multicolumn{2}{|c|}{$\mathrm{N}$} & \multicolumn{2}{|c|}{ TS } & \multicolumn{2}{|c|}{ STS } \\
\hline \multirow{3}{*}{ Warna } & $\mathrm{F} 1$ & 0 & $\begin{array}{l}\text { Sangat } \\
\text { Lemah }\end{array}$ & 50 & Cukup & 35 & Lemah & 15 & $\begin{array}{l}\text { Sangat } \\
\text { Lemah }\end{array}$ & 0 & $\begin{array}{l}\text { Sangat } \\
\text { Lemah }\end{array}$ \\
\hline & $\mathrm{F} 2$ & 0 & $\begin{array}{l}\text { Sangat } \\
\text { Lemah }\end{array}$ & 65 & Kuat & 25 & Lemah & 10 & $\begin{array}{l}\text { Sangat } \\
\text { Lemah }\end{array}$ & 0 & $\begin{array}{l}\text { Sangat } \\
\text { Lemah }\end{array}$ \\
\hline & F3 & 0 & $\begin{array}{l}\text { Sangat } \\
\text { Lemah }\end{array}$ & 5 & $\begin{array}{l}\text { Sangat } \\
\text { Lemah }\end{array}$ & 35 & Lemah & 60 & Cukup & 0 & $\begin{array}{l}\text { Sangat } \\
\text { Lemah }\end{array}$ \\
\hline \multirow{3}{*}{ Aroma } & $\mathrm{F} 1$ & 0 & $\begin{array}{l}\text { Sangat } \\
\text { Lemah }\end{array}$ & 30 & Lemah & 70 & Kuat & 0 & $\begin{array}{l}\text { Sangat } \\
\text { Lemah }\end{array}$ & 0 & $\begin{array}{l}\text { Sangat } \\
\text { Lemah }\end{array}$ \\
\hline & $\mathrm{F} 2$ & 0 & $\begin{array}{l}\text { Sangat } \\
\text { Lemah }\end{array}$ & 20 & $\begin{array}{l}\text { Sangat } \\
\text { Lemah }\end{array}$ & 70 & Kuat & 10 & $\begin{array}{l}\text { Sangat } \\
\text { Lemah }\end{array}$ & 0 & $\begin{array}{l}\text { Sangat } \\
\text { Lemah }\end{array}$ \\
\hline & F3 & 0 & $\begin{array}{l}\text { Sangat } \\
\text { Lemah }\end{array}$ & 0 & $\begin{array}{l}\text { Sangat } \\
\text { Lemah }\end{array}$ & 45 & Cukup & 55 & Cukup & 0 & $\begin{array}{l}\text { Sangat } \\
\text { Lemah }\end{array}$ \\
\hline \multirow{3}{*}{ Rasa } & $\mathrm{F} 1$ & 0 & $\begin{array}{l}\text { Sangat } \\
\text { Lemah }\end{array}$ & 60 & Cukup & 35 & Lemah & 5 & $\begin{array}{l}\text { Sangat } \\
\text { Lemah }\end{array}$ & 0 & $\begin{array}{l}\text { Sangat } \\
\text { Lemah }\end{array}$ \\
\hline & $\mathrm{F} 2$ & 0 & $\begin{array}{l}\text { Sangat } \\
\text { Lemah }\end{array}$ & 55 & Cukup & 30 & Lemah & 15 & $\begin{array}{l}\text { Sangat } \\
\text { Lemah }\end{array}$ & 0 & $\begin{array}{l}\text { Sangat } \\
\text { Lemah }\end{array}$ \\
\hline & F3 & 0 & $\begin{array}{l}\text { Sangat } \\
\text { Lemah }\end{array}$ & 5 & $\begin{array}{l}\text { Sangat } \\
\text { Lemah }\end{array}$ & 10 & $\begin{array}{l}\text { Sangat } \\
\text { Lemah }\end{array}$ & 85 & Kuat & 0 & $\begin{array}{l}\text { Sangat } \\
\text { Lemah }\end{array}$ \\
\hline
\end{tabular}

* Sampel : F1 (Formulasi satu), F2 (Formulasi dua), F3 (Formulasi tiga)

*Presepsi : SS (Sangat Suka); S (Suka); N (Netral); TS (Tidak Suka), STS (Sangat Tidak Suka)

*Kriteria Skor \% : Sangat lemah (0-20); Lemah (21-40); Cukup (41-60); Kuat (61-80); Sangat kuat (81-100), Sumber: (Riduwan, 2009)

Tabel 1.3 menunjukan hasil presentase uji kesukaan dari 20 responden. Hasil persentase uji kesukaan responden tersebut kemudian diubah kedalam diagram uji kesukaan yang dapat dilihat pada Gambar 1.1. 


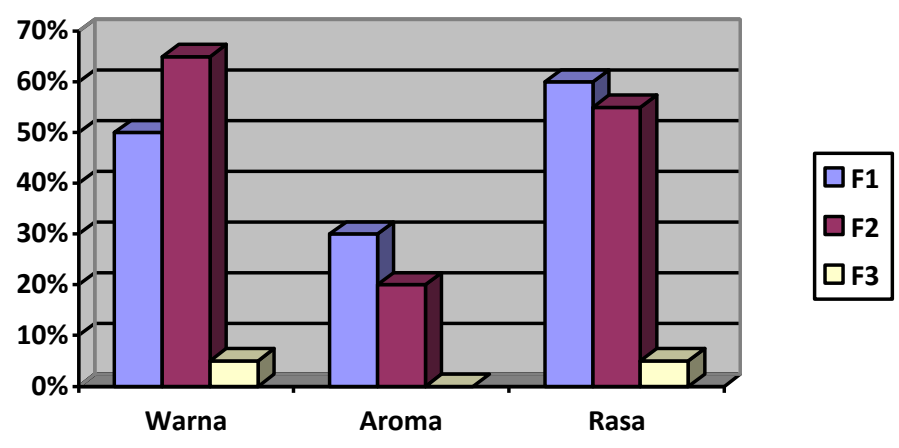

Gambar 1.1 Diagram Uji Kesukaan

Dilihat dari Gambar 1.1 uji kesukaan warna pada sampel formulasi satu, $50 \%$ responden menyatakan suka terhadap warna sediaan. Pada sampel formulasi dua, $65 \%$ responden menyatakan suka terhadap warna sediaan. Pada sampel formulasi tiga, $5 \%$ responden menyatakan suka terhadap warna sediaan.

Dilihat dari Gambar 1.1 uji kesukaan aroma pada sampel formulasi satu, 30\% responden menyatakan suka terhadap aroma sediaan. Pada sampel formulasi dua, $20 \%$ responden menyatakan suka terhadap aroma sediaan. Pada sampel formulasi tiga, $0 \%$ responden menyatakan suka terhadap aroma sediaan.

Dilihat dari Gambar 1.1 uji kesukaan rasa pada sampel formulasi satu, 60\% responden menyatakan suka terhadap rasa sediaan. Pada sampel formulasi dua, 55\% responden menyatakan suka terhadap rasa sediaan. Pada sampel formulasi tiga, 5\% responden menyatakan suka terhadap rasa sediaan.

\section{PEMBAHASAN}

\section{Uji Organoleptik}

Berdasarkan hasil pengamatan yang tertera pada Tabel 4.2 menunjukkan hasil pengujian organoleptik selama tiga minggu berturut-turut bahwa sediaan bakso dengan penyimpanan suhu dingin yang dilakukan peneliti tidak timbul perubahan dalam hal warna, aroma, tekstur, rasa dan ketiga sampel yang penyimpanannya dengan suhu dingin selama 3 minggu tidak menimbulkan tanda-tanda tumbuhnya jamur sehingga sangat direkomendasikan untuk produk bakso herbal ini agar disimpan pada suhu dingin atau disimpan pada kulkas pendingin. Hal ini diperkirakan karena proses pengambilan bahan baku yang baik sampai dengan proses pembuatan yang baik dan terjaga kebersihannya sehingga tidak menjadi media untuk pertumbuhan jamur dan dapat meminimalisir pertumbuhan jamur serta tata penyimpanan sediaan yang disimpan dalam wadah tertutup rapat dapat menjaga stabilitas dan tidak adanya perubahan negatif dalam sediaan yang dibuat. Selain itu kemungkinan dikarenakan faktor suhu dingin yang dapat memperpanjang penyimpanan sediaan pangan[16].

Pendinginan merupakan salah satu proses yang umum digunakan untuk mengatasi proses perkembangbiakan mikroorganisme pada bahan makanan. Prinsip proses pendinginan adalah mengurangi atau menghambat aktifitas mikroorganisme. Penyimpanan pada suhu dingin pertumbuhan bakteri terjadi secara lambat, hal ini disebabkan bahwa prinsip penyimpanan pada suhu dingin adalah menghambat atau memperlambat kecepatan reaksi metabolisme mikroorganisme sehingga dengan suhu dingin kecepatan reaksi akan berkurang, tetapi penggunaan suhu dingin tidak dapat membunuh mikroorganisme [16].

Sementara pada suhu ruang hanya bertahan selama 2 hari saja. Dari ketiga sampel dengan perbandingan penyimpanan di suhu ruang dan suhu dingin setelah dilakukan pengujian organoleptik 
didapatkan hasil perbedaan yang mencolok pada stabilitas sediaan meliputi warna, aroma, tekstur, rasa dan jamur. Pada penyimpanan di suhu ruang didapatkan hasil pada hari kedua sediaan bakso herbal sudah terjadi perubahan warna, aroma, tekstur, rasa dan tumbuhnya jamur. Hasil tersebut sejalan dengan yang diungkapkan oleh Wardaniati dan Setyaningsih (2009) yaitu masa simpan bakso dalam kondisi normal penyimpanan hanya bisa bertahan 2 hari[5]. Bakso merupakan produk olahan daging yang memiliki nutrisi tinggi sehingga masa simpan maksimalnya adalah 1 hari[17]. Sehingga penelitian pada sampel dengan penyimpanan suhu ruang hanya diteliti 2 hari saja.

Pada suhu ruang proses perkembangbiakan mikroorganisme akan lebih cepat terjadi, karena pada suhu tersebut merupakan suhu yang optimal untuk pertumbuhan mikroorganisme. Pada suhu tersebut akan terjadi perubahan kegiatan zat-zat dan mikroorganisme yang dapat menimbulkan bertambahnya jumlah mikroorganisme di dalam bahan makanan[16]. Karakteristik bakso herbal pada suhu ruang cepat mengalami pertumbuhan jamur lebih cepat karena kandungan air pada jamur tiram putih. Kandungan air pada jamur tiram putih segar yaitu sebesar 90,97\%[18].

Kadar air sangat penting sekali dalam menentukan daya awet dari bahan pangan, karena mempengaruhi sifat-sifat fisik, perubahan kimia, enzimatis dan mikrobiologis bahan pangan. Usaha untuk membuat masa simpan bakso menjadi lebih lama sudah banyak dilakukan, salah satunya yaitu dengan penyimpanan pada suhu rendah atau suhu dingin ${ }^{[19]}$.

\section{Uji Kesukaan}

Warna pada sampel formulasi satu, 50\% responden menyatakan suka terhadap warna sediaan. Pada sampel formulasi dua, $65 \%$ responden menyatakan suka terhadap warna sediaan. Pada sampel formulasi tiga, 5\% responden menyatakan suka terhadap warna sediaan. Dari ketiga formulasi tersebut, warna yang paling disukai oleh responden yaitu sampel F2 sebanyak 65\% responden dengan kriteria kuat. Hal ini disebabkan oleh warna (coklat) yang timbul akibat penambahan bubuk kayu manis sangat unik. Namun apabila penambahan bubuk kayu manis terlalu banyak seperti pada sampel F3 akan mengakibatkan warna yang sangat gelap. Bubuk kayu manis mempunyai warna coklat. Oleh karena itu, semakin tinggi penggunaan bubuk kayu manis maka semakin mempengaruhi warna makanan yang dihasilkan yaitu warna coklat gelap ${ }^{[20] \text {. }}$

Aroma pada sampel formulasi satu, $30 \%$ responden menyatakan suka terhadap aroma sediaan. Pada sampel formulasi dua, $20 \%$ responden menyatakan suka terhadap aroma sediaan. Pada sampel formulasi tiga, $0 \%$ responden menyatakan suka terhadap aroma sediaan. Dari ketiga formulasi tersebut, aroma yang paling disukai oleh responden yaitu sampel F1 sebanyak 30\% responden. Hal ini diduga responden kurang menyukai aroma dari kayu manis sehingga apabila bakso jamur tiram putih dan bubuk kayu manis, maka aroma kayu manis yang akan lebih dominan daripada aroma jamur tiram putih.

Rasa pada sampel formulasi satu, $60 \%$ responden menyatakan suka terhadap rasa sediaan. Pada sampel formulasi dua, 55\% responden menyatakan suka terhadap rasa sediaan. Pada sampel formulasi tiga, 5\% responden menyatakan suka terhadap rasa sediaan. Dari ketiga formulasi tersebut, rasa yang paling disukai oleh responden yaitu sampel $\mathrm{F} 1$ sebanyak $60 \%$ responden. Hal ini diduga responden kurang menyukai rasa dari kayu manis. Penambahan bubuk kayu manis mempunyai pengaruh cita rasa yang kuat ${ }^{[20]}$. Cita rasa bakso jamur tiram tidak kalah enak dengan bakso daging sapi, karena pada dasarnya jamur tiram memiliki tekstur yang hampir sama dengan daging[21].

\section{SIMPULAN}

Berdasarkan hasil penelitian yang telah dilakukan, maka dapat disimpulkan bahwa pembuatan sediaan bakso herbal dilakukan dengan cara mencampurkan jamur tiram putih dengan perbandingan bubuk kayu manis $0: 2,5$; 5 gram dan bumbu pelengkap dengan tempat penyimpanan suhu ruang dan suhu dingin. 
Hasil uji organoleptik didapatkan sediaan bakso herbal yang stabil selama tiga minggu adalah sampel F1, F2, F3 namun hanya dipenyimpanan pada suhu dingin saja.

Hasil uji kesukaan yang mendapatkan persentase tertinggi untuk warna sediaan adalah F2 sementara persentase tertinggi pada aroma dan rasa adalah F1. Namun disarankan untuk menggunakan F2.

\section{Saran}

Perlu dilakukan penelitian lanjutan seperti uji khasiat pada bakso herbal dari jamur tiram putih (Pleurotus ostreatus) dan kayu manis (Cinnamomum burmannii) untuk menurunkan kolesterol dan uji efektivitas penambahan kayu manis pada sediaan bakso herbal pada penyimpanan suhu dingin. Saran untuk penelitian selanjutnya adalah penggantian pengawet pada sediaan, selain kayu manis.

\section{DAFTAR PUSTAKA}

1. Sihotang HT. (2014). Sistem Pakar Mendiagnosa Penyakit Kolesterol Pada Remaja Dengan Metode Certainty Factor (CF) Berbasis Web. Jurnal Mantik Penusa. Volume 15 Nomor 1. STMIK Pelita Nusantara Medan.

2. Yani M. (2015). Mengendalikan KadarKolesterol Pada Hiperkolesterolemia. Jurnal Olahraga Prestasi, Volume 11, Nomor 2. Universitas Negeri Yogyakarta.

3. Oktaviani, W. D., L.D. Saraswati dan M. Z. Rahfiludin. (2012). Hubungan kebiasaan konsumen fast food, aktivitas fisik, pola konsumsi, karakteristik remaja dan orang tua dengan indeks massa tubuh (imt) (sudi kasus pada siswa sma negeri 9 semarang tahun 2012). Jurnal Kesehatan Masyarakat 1(2): 542-553.

4. Chakim, L., B. Dwiloka dan Kusrahayu. (2013). Tingkat kekenyalan, daya mengikat air, kadar air, dan kesukaan pada bakso daging sapi dengan substitusi jantung sapi. Jurnal Animal Agriculture 2 (1): 97-104.

5. Wardaniati dan Setyaningsih, (2009). Pembuatan Chitosan dari Kulit Udang
Dan Aplikasinya Untuk Pengawetan Bakso.

6. Yernisa, Uliyarti dan Ade Yulia. (2007). Pengaruh Konsentrasi Khitosan dan Lama Perendaman terhadap Umur Simpan Bakso Ikan Nila (oreocromis, sp) Pada Suhu Ruang. Laporan Penelitian. Fakultas Pertanian. Universitas Jambi.

7. Kusumaningrum, Indrati dan Sutono Doddy. (2008). Kajian Mutu Kimiawi Bakso Asap dari Udang Putih (Penaeus merguiensis) Pada Berbagai Variasi Konsentrasi dan Waktu Perendaman dalam Asap Cair. Jurnal Teknologi Pertanian 4(1) : 25-30, Agustus 2008.

8. Wardhana S.Mita R.A. (2010). Reaksi Pencoklatan Pada Dodol Rumput Laut Dengan Penambahan Ekstrak Kayu Manis yang Berbeda Konsentrasi Selama Penyimpanan. Skripsi. Fakultas Perikanan dan Ilmu Kelautan. Universitas Diponegoro. Semarang.

9. Yulia, A, dkk. 2013. Pengaruh Konsentrasi Ekstrak Kulit Kayu Manis dan Lama Perendaman Terhadap Umur Simpan Bakso Ikan Patin Pada Suhu Ruang. Fakultas Pertanian. Universitas Jambi. Jambi.

10. Tjokrokusumo, D. (2008). Untuk meningkatkan ketahanan pangan dan rehabilitasi lingkungan. JRL, 4(1), 5362.

11. Purbaningrum, L., \& Orbayinah, S. (2016). Pengaruh Kapsul Pleuratus ostreatus terhadap Kadar Kolesterol pada Lanjut Usia Hiperkolesterolemia. Mutiara Medika: Jurnal Kedokteran dan Kesehatan, 12(2), 109-115.

12. Muhammad, A. (2009). Waspadai Kolesterol Tinggi. Bukubiru.

13. Riduwan (2009). Dasar-dasar Statistika. Bandung: Alfabeta.

14. Suryono C, Lestari N \& Triana RD. (2018). Uji Kesukaan dan Organoleptik Terhadap 5 kemasan dan Produk Kepulauan Seribu Secara Deskriptif. Jurnal Pariwisata, Vol. 5 No. 2.

15. Yuliantoro, N. (2019). Inovasi Cheescake Menggunakan Bahan 
Kacang Buncis Sebagai Pengganti Terigu. Jurnal Media Wisata: Wahana Informasi Pariwisata, 17 (1).

16. Wardhani, S. M. D. (2016). Pengaruh Suhu dan Waktu Penyimpanan terhadap Pertumbuhan Bakteri Staphylococcus Aureus pada Makanan Sosis Siap Santap Di Medan.

17. Wicaksono, D. A. (2007). Pengaruh metode aplikasi kitosan, tanin, natrium metabisulfit dan mix pengawet terhadap umur simpan bakso daging sapi pada suhu ruang. Skripsi. Fakultas Teknologi Pertanian. Institut Pertanian Bogor. Bogor.

18. Laksono, M. A., Bintoro, V. P., \& Mulyani, S. (2012). Daya Ikat Air, Kadar Air, dan Protein Nugget Ayam yang Disubstitusi dengan Jamur Tiram Putih (Pleurotus Ostreatus). Animal Agriculture Journal, 1(1), 685-696.

19. Buckle, K. A., R. A. Edward, G. H. Fleet dan M. Wotton. (2009). Ilmu Pangan. Universitas Indonesia Press, Jakarta. (Diterjemahkan oleh Hari Purnomo dan Adiono).

20. Anto, A., \& Rato, R. (2018). Pengaruh Penambahan Bubuk Kayu Manis (Cinnamomum Burmannii) terhadap Sifat Kimia dan Total Mikroba pada Nugget Ayam. Agropolitan, 5(1), 1-11.

21. Prianjoyo, A. (2012). Bakso Dari Jamur Tiram. Skripsi. Sekolah Tinggi Manajemen Informatika dan Komputer Stimik Amikom Yogyakarta. Yogyakarta. 